\title{
Role of Lymphography in Carcinoma of the Prostate
}

\author{
R. M. PAXTON, GRANT WILLIAMS, J. S. MACDONALD
}

the contrast medium in diagnostic amounts for about a year. Thus, plain radiographs of the abdomen and pelvis afford a simple means of assessing the effects of treatment in those patients with involved nodes. In addition, initially normal lymphograms when followed-up regularly by repeat radiographs may reveal new and clinically unsuspected lymphatic metastases.

The technique and complications have been previously described by Macdonald (1973). Patients with carcinoma of the prostate are often elderly, but in only a few cases were we unable to perform the investigation because of concurrent cardiorespiratory illness. The technique is repeatable and "refill" lymphograms are not technically difficult. No significant complications were encountered in the series though complications do occur and sensible precautions must be taken (Fischer, 1969; Macdonald, 1974). static capsule- $41 \%$ had positive lymphograms. The inaccuracy of acid phosphatase estimations in detecting early extraprostatic spread is shown and compared with the greater accuracy of lymphography. Lymphography should be used as an initial investigation in all cases where aggressive therapy is being considered, and the importance of regular follow-up radiographs is emphasized.

\section{Introduction}

Adenocarcinoma of the prostate gland spreads directly through the capsule to involve adjacent structures, by the vertebral venous plexus-giving rise to distant metastases-and by lymphatic drainage to the internal iliac lymph nodes on each side of the pelvis and then to the common iliac and paraaortic groups. Lymphatic spread of carcinoma of the prostate has received scant attention in the British literature. Our series shows that there is a high incidence of lymphatic spread even in early cases.

Now that localized radiotherapy to the prostate is an accepted form of definitive treatment (Bloom and Hendry, 1973; Ray et al., 1973) and chemotherapy with methotrexate is being used in the later stages of the disease at the Royal Marsden Hospital an accurate pretreatment description of the regional lymph nodes and beyond seems desirable. Nodes shown to be involved by tumour deposits should be included in any therapy plan or a different mode of treatment may have to be considered in the light of lymphographic evidence of tumour spread. Similarly, if radical prostatectomy is contemplated in early cases preoperative demonstration of lymph node involvement may alter treatment plans.

Though lymphography opacifies only the external iliac, common iliac, and paraaortic groups and not the regional nodes our figures show that there is a sufficiently high incidence of involvement of the opacified nodes to warrant routine pretreatment lymphography in any case where aggressive therapy is considered.

When lymphograms are performed with an oily fluid containing iodine (iodized oil fluid injection) the lymph nodes retain \footnotetext{
Department of Radiodiagnosis, Royal Marsden Hospital and
Institute of Cancer Research, Fulham Road, London

R. M. PAXTON, M.B., F.F.R., Senior Registrar in Radiodiagnosis J. S. MACDONALD, M.B., F.F.R., Consultant Radiologist

Department of Surgery, Royal Marsden Hospital and Institute of Cancer Research, Fulham Road, London

GRANT WILLIAMS, M.S., F.R.C.s., Consultant Urologist
}

\section{Patients and Methods}

Bilateral pedal lymphography was performed in 83 patients with histologically proved adenocarcinoma of the prostate seen at the Royal Marsden Hospital since 1968.

Previous reports on the results of lymphography have not separated new cases from those with longstanding, advanced disease and we felt that this distinction was important if a true perspective of lymphatic involvement was to be achieved. Forty-five of our patients were new cases-that is, referred immediately after histological evidence of the disease had been found for the first time or presenting directly to the hospital with no previous evidence of disease. They had received no treatment except a biopsy, transurethral resection, or open prostatectomy (five cases). The remaining 38 patients were classified as late or "old" cases, having been referred for radiotherapy or chemotherapy because of failure of hormonal treatment.

The case records and radiographs of these patients were reviewed by two of us (R.P. and G.W.). Tumour staging, histological confirmation and grade, and acid phosphatase estimations at the time of lymphography were recorded. The lymphograms were reviewed to detect the presence of tumour deposits in the opacified lymph nodes and follow-up films were reviewed to assess progress. Skeletal surveys and bone and liver scans were also reviewed for possible metastases.

The classification of carcinoma of the prostate has been the subject of much debate. The U.I.C.C. classification, which incorporates the T.N.M. system, received final approval in May 1974, and was used in this series. The clinical classification of the primary tumour is as follows: $T$, primary tumour; $\mathrm{TX}$, incidental finding of carcinoma in an operative specimen with no preoperative evidence or suspicion of carcinoma; TO, metastatic disease with no evidence of primary disease; $\mathrm{T} 1$, solitary nodule with smooth surface occupying less than one lobe and surrounded by compressible tissue; T2, tumour with smooth surface confined to the prostate and occupying one lobe or more; T3, tumour extending beyond the prostate with or without involvement of the seminal vesicles or the bladder; $\mathrm{T} 4$, tumour fixed to the pelvic wall or involving adjoining organs. The histopathological grades are: GX, no information available; GO, ungradeable; G1 low grade; G2, medium grade; G3, high grade.

Histological confirmation of metastatic involvement of lymph nodes was obtainable in only six of the new cases and 10 of the late cases. In experienced hands, however, with meticulous 
technique and the evaluation of the nodes on follow-up films lymphography is a very accurate investigation. The persistence of the contrast medium in the nodes allows their behaviour as well as their initial appearance to be assessed and involvement by a deposit should only be diagnosed if the suspicious area not only looks like tumour but behaves like tumour.

\section{Results}

Not unexpectedly there was a higher overall incidence of lymphatic involvement in the late cases, $76.3 \%$, than in the new cases, $55.6 \%$ (tables I and II). New cases with T1 and T2 tumoursthat is, those still localized within the capsule-had an overall $41 \%(7 / 17)$ incidence of lymph node metastases shown by lymphography. This coincides with the experience of Castellino (1974) who in a prospective study still to be published quotes a $35-40 \%$ incidence of histologically documented lymph node metastases, often to the paraaortic glands, in patients with disease clinically, biochemically, and radiologically confined to the prostate-that is, $\mathrm{T} 1$ and $\mathrm{T} 2$.

TABLE I-Extent of Local Tumour and Lymphogram Results in New Cases

\begin{tabular}{c|c|c|c}
\hline $\begin{array}{c}\text { Local Tumour } \\
\text { Grade }\end{array}$ & $\begin{array}{c}\text { No. of } \\
\text { Patients }\end{array}$ & $\begin{array}{c}\text { No. (\%) } \\
\text { Positive on } \\
\text { Lymphography }\end{array}$ & $\begin{array}{c}\text { No. (\%) } \\
\text { Negative on } \\
\text { Lymphography }\end{array}$ \\
\hline TX & 5 & 0 & $5(100)$ \\
T1 & 4 & $1(25)$ & $3(75)$ \\
T2 & 13 & $6(46 \cdot 2)$ & $7(53 \cdot 8)$ \\
T3 & 10 & $6(60)$ & $4(40)$ \\
T4 & 13 & $12(92 \cdot 3)$ & $1(7 \cdot 7)$ \\
\hline Total & 45 & $25(55 \cdot 6)$ & $20(44 \cdot 4)$ \\
\hline
\end{tabular}

TABLE II-Extent of Local Tumour and Lymphogram Results in Late Cases

\begin{tabular}{c|c|c|c}
$\begin{array}{c}\text { Local Tumour } \\
\text { Grade }\end{array}$ & $\begin{array}{c}\text { No. of } \\
\text { Patients }\end{array}$ & $\begin{array}{c}\text { No. (\%) } \\
\text { Positive on } \\
\text { Lymphography }\end{array}$ & $\begin{array}{c}\text { No. (\%) } \\
\text { Negative on } \\
\text { Lymphography }\end{array}$ \\
\hline T2 & 2 & $2(100)$ & 0 \\
T3 & 13 & $9(69 \cdot 2)$ & $4(30 \cdot 8)$ \\
T4 & 23 & $18(78 \cdot 3)$ & $5(21 \cdot 7)$ \\
\hline Total & 38 & $29(76 \cdot 3)$ & $9(23 \cdot 7)$ \\
\hline
\end{tabular}

Altogether $60 \%(6 / 10)$ of new T3 tumours and $92 \cdot 3 \%(12 / 13)$ of new T4 tumours showed lymphatic deposits. Involvement of paraaortic nodes as well as pelvic nodes in $15.4 \%$ of T2 tumours and $61.5 \%$ of T4 tumours in new cases should be noted (tables III and IV). There did not seem to be any firm correlation between the degree of malignancy of the primary tumour and the incidence of lymphatic metastases (table V).

The incidence of lymphatic metastases compared with the incidence of skeletal metastases as shown by skeletal surveys and radioisotope bone scans is shown in tables VI and VII. Altogether $46.9 \%$ of new cases and $64.3 \%$ of late cases without bony metastases had lymphographic evidence of lymph node deposits. Of those new cases with bony deposits $76.9 \%$ had involved nodes at lymphography.

Grossman et al. (1974) showed that serum acid phosphatase
TABLE III-Distribution of Involved Nodes in New Cases

\begin{tabular}{c|c|c|c|c}
\hline $\begin{array}{c}\text { Local } \\
\text { Gumour } \\
\text { Grade }\end{array}$ & $\begin{array}{c}\text { No. of } \\
\text { Patients }\end{array}$ & $\begin{array}{c}\text { No. (\%) with } \\
\text { Pelvic Nodes } \\
\text { Involved }\end{array}$ & $\begin{array}{c}\text { No. (\%) with } \\
\text { Paraaortic } \\
\text { and Pelvic } \\
\text { Nodes Involved }\end{array}$ & $\begin{array}{c}\text { No. (\%) } \\
\text { Negative on } \\
\text { Lymphography }\end{array}$ \\
\hline TX & 5 & 0 & 0 & $5(100)$ \\
T1 & 4 & $1(25)$ & 0 & $3(75)$ \\
T2 & 13 & $4(30 \cdot 8)$ & $2(15 \cdot 4)$ & $7(53 \cdot 8)$ \\
T3 & 10 & $5(50)$ & $1(10)$ & $4(40)$ \\
T4 & 13 & $4(30 \cdot 8)$ & $8(61 \cdot 5)$ & $1(7 \cdot 7)$ \\
\hline Total & 45 & $14(31 \cdot 2)$ & $11(24 \cdot 4)$ & $20(44 \cdot 4)$ \\
\hline
\end{tabular}

TABLE IV-Distribution of Involved Nodes in Late Cases

\begin{tabular}{|c|c|c|c|c|}
\hline $\begin{array}{c}\text { Local } \\
\text { Tumour } \\
\text { Grade }\end{array}$ & $\begin{array}{c}\text { No. of } \\
\text { Patients }\end{array}$ & $\begin{array}{l}\text { No. }(\%) \text { with } \\
\text { Pelvic Nodes } \\
\text { Involved }\end{array}$ & $\begin{array}{l}\text { No. (\%) with } \\
\text { Paraaortic } \\
\text { and Pelvic } \\
\text { Nodes Involved }\end{array}$ & $\begin{array}{c}\text { No. }(\%) \\
\text { Negative on } \\
\text { Lymphography }\end{array}$ \\
\hline $\begin{array}{l}\text { T2 } \\
\text { T3 } \\
\text { T4 }\end{array}$ & $\begin{array}{r}2 \\
13 \\
23\end{array}$ & $\begin{array}{c}2(100) \\
5(38 \cdot 4) \\
14(60 \cdot 9)\end{array}$ & $\begin{array}{l}0 \\
4(30 \cdot 8) \\
4(17 \cdot 4)\end{array}$ & $\begin{array}{l}0 \\
4(30 \cdot 8) \\
5(21 \cdot 7)\end{array}$ \\
\hline Total & 38 & $21(55 \cdot 3)$ & $8(21 \cdot 1)$ & $9(23.6)$ \\
\hline
\end{tabular}

TABLE VI-Bone Metastases* and Lymphogram Results in New Cases

\begin{tabular}{|c|c|c|c|}
\hline & $\begin{array}{l}\text { No. of } \\
\text { Patients }\end{array}$ & $\begin{array}{c}\text { No. }(\%) \\
\text { Positive on } \\
\text { Lymphography }\end{array}$ & $\begin{array}{c}\text { No. }(\%) \\
\text { Negative on } \\
\text { Lymphography }\end{array}$ \\
\hline $\begin{array}{l}\text { Bone metastases present } \\
\text { Bone metastases absent }\end{array}$ & $\begin{array}{l}13 \\
32\end{array}$ & $\begin{array}{l}10(76 \cdot 9) \\
15(46 \cdot 9)\end{array}$ & $\begin{array}{r}3(23 \cdot 1) \\
17(53 \cdot 1)\end{array}$ \\
\hline
\end{tabular}

*As measured by skeletal survey and radioisotope bone scan.

TABLE VII-Bone Metastases* and Lymphogram Results in Late Cases

\begin{tabular}{l|c|c|c}
\hline & $\begin{array}{c}\text { No. of } \\
\text { Patients }\end{array}$ & $\begin{array}{c}\text { No. (\%) } \\
\text { Positive on } \\
\text { Lymphography }\end{array}$ & $\begin{array}{c}\text { No. (\%) } \\
\text { Legative on } \\
\text { Lymphography }\end{array}$ \\
$\begin{array}{l}\text { Bone metastases present } \\
\text { Bone metastases absent }\end{array}$ & 24 & $17(70 \cdot 8)$ & $7(29 \cdot 2)$ \\
$9(64 \cdot 3)$ & $5(35 \cdot 7)$
\end{tabular}

*As measured by skeletal survey and radioisotope bone scan.

levels were not as accurate an indicator of the early spread of the disease as lymphography and we confirmed this (tables VIII and IX). Of new cases with normal acid phosphatase levels at the time of lymphography $48.3 \%$ had lymph node deposits whereas $81 \cdot 8 \%$ of new cases with raised acid phosphatase levels had positive lymphograms.

Two patients with advanced disease and liver metastases had positive lymphograms, but out of two patients with histologically proved involved cervical lymph nodes only one had lymphographic evidence of involved abdominal nodes. One patient with lung and bone metastases had a normal lymphogram which was confirmed at necropsy.

Six new cases $(13.3 \%)$ with initially normal lymphograms subsequently developed lymph node deposits visible on followup radiographs, but there was no clinical evidence of lymphatic spread. Five of them developed pelvic lymph node deposits and the remaining patient developed a deposit in an opacified left supraclavicular node visible on a chest $x$-ray picture. The

TABLE v-Pathological Tumour Grading and Lymphogram Result in All Cases. Results are Numbers of Patients

\begin{tabular}{|c|c|c|c|c|c|c|c|c|c|}
\hline \multirow[b]{2}{*}{$\begin{array}{l}\text { Local Tumour } \\
\text { Grade }\end{array}$} & \multirow{2}{*}{$\begin{array}{l}\text { No. of } \\
\text { Patients }\end{array}$} & \multicolumn{2}{|c|}{ G1 } & \multicolumn{2}{|c|}{ G2 } & \multicolumn{2}{|c|}{ G3 } & \multicolumn{2}{|c|}{ GX } \\
\hline & & $\begin{array}{c}\text { Lymphogram } \\
\text { Negative }\end{array}$ & $\begin{array}{c}\text { Lymphogram } \\
\text { Positive }\end{array}$ & $\begin{array}{c}\text { Lymphogram } \\
\text { Negative }\end{array}$ & $\begin{array}{c}\text { Lymphogram } \\
\text { Positive }\end{array}$ & $\begin{array}{c}\text { Lymphogram } \\
\text { Negative }\end{array}$ & $\begin{array}{c}\text { Lymphogram } \\
\text { Positive }\end{array}$ & $\begin{array}{l}\text { Lymphogram } \\
\text { Negative }\end{array}$ & $\begin{array}{c}\text { Lymphogram } \\
\text { Positive }\end{array}$ \\
\hline $\begin{array}{l}\text { TX } \\
\text { T1 } \\
\text { T2 } \\
\text { T3 } \\
\text { T4 }\end{array}$ & $\begin{array}{r}5 \\
4 \\
15 \\
23 \\
36\end{array}$ & $\begin{array}{l}1 \\
5 \\
4\end{array}$ & $\begin{array}{l}2 \\
4 \\
8\end{array}$ & $\begin{array}{l}2 \\
2 \\
2 \\
4 \\
4\end{array}$ & $\begin{array}{r}1 \\
5 \\
9 \\
17\end{array}$ & $\begin{array}{l}2 \\
1 \\
2\end{array}$ & $\begin{array}{l}1 \\
2 \\
1\end{array}$ & & 4 \\
\hline Total & 83 & 10 & 14 & 14 & 32 & 5 & 4 & & 4 \\
\hline
\end{tabular}


TABLE VIII-Acid Phosphatase Estimation at Time of Lymphogram in 40 New Cases

\begin{tabular}{l|c|c|c}
\hline & $\begin{array}{c}\text { No. of } \\
\text { Patients }\end{array}$ & $\begin{array}{c}\text { No. (\%) } \\
\text { Positive on } \\
\text { Lymphography }\end{array}$ & $\begin{array}{c}\text { No. (\%) } \\
\text { Negative on } \\
\text { Lymphography }\end{array}$ \\
\hline $\begin{array}{l}\text { Raised acid phosphatase } \\
\text { Normal acid phosphatase }\end{array}$ & $\begin{array}{c}11 \\
29\end{array}$ & $\begin{array}{r}9(81 \cdot 8) \\
14(48 \cdot 3)\end{array}$ & $\begin{array}{r}2(18 \cdot 2) \\
15(51 \cdot 7)\end{array}$ \\
\hline
\end{tabular}

TABLE IX-Acid Phosphatase Estimation at Time of Lymphogram in 29 Late Cases

\begin{tabular}{l|c|c|c}
\hline & $\begin{array}{c}\text { No. of } \\
\text { Patients }\end{array}$ & $\begin{array}{c}\text { No. (\%) } \\
\text { Positive on } \\
\text { Lymphography }\end{array}$ & $\begin{array}{c}\text { No. (\%) } \\
\text { Negative on } \\
\text { Lymphography }\end{array}$ \\
\hline $\begin{array}{l}\text { Raised acid phosphatase } \\
\text { Normal acid phosphatase }\end{array}$ & 18 & $\begin{array}{r}16(88 \cdot 9) \\
9(81 \cdot 8)\end{array}$ & $\begin{array}{r}2(11 \cdot 1) \\
2(18 \cdot 2)\end{array}$ \\
\hline
\end{tabular}

deposits appeared between six and 15 months after the lymphograms. (These cases are not included in the tables as having positive results.)

\section{Discussion}

In 1959 Flocks et al. demonstrated the spread of prostatic cancer by the lymphatic system and later that year Whitmore and MacKenzie (1959) confirmed this finding. Arduino and Glucksman (1962) reported lymph node involvement in $32 \%$ $(14 / 44)$ of patients with disease clinically within the prostatic capsule who had undergone pelvic lymphadenectomy. Only two of these cases had deposits limited to the internal iliac group. Grossman et al. (1974) published the results of bilateral pedal lymphography in 58 patients with prostatic cancer and showed an $81 \%$ incidence of lymphatic involvement. McCullough et al. (1974) in a surgical series of 61 patients had histological proof of lymph node involvement in $61 \%$; stage $\mathrm{B}$ had a $25 \%$ incidence, stage C $51 \%$, and stage D $82 \%$. Castellino et al. (1973) published a smaller series of 18 patients with cancer confined to the prostatic bed. All patients had lymphograms and then underwent staging laparotomy; nine patients had histological proof of lymph node metastases, and in eight of these cases the preoperative lymphograms showed involved lymph nodes. The remaining case had one opacified node involved by a microscopic deposit which would not have been demonstrable by lymphography.

In our series of 45 new cases $55.6 \%$ had lymphographic evidence of lymph node metastases. A higher figure of $76.3 \%$ was seen in the late cases. This gives an overall incidence of $65 \%(54 / 83)$, which is lower than that given by Grossman et al. (1974) but is comparable to that of McCullough et al. (1974). Involvement of the paraaortic lymph nodes in $15 \%$ of $\mathrm{T} 2$ tumours seemed to be important information in the management of these patients, as was the $41 \%$ incidence of lymph node deposits in new T1 and T2 tumours.

Whitmore and MacKenzie (1959) showed that patients with normal serum acid phosphatase levels may have extraprostatic spread of cancer. McCullough et al. (1974) described 56 patients with normal serum acid phosphatase levels of whom $59 \%$ (33/56) had histological proof of lymph node deposits. We have shown that $46.9 \%$ of new cases without skeletal metastases and
$48.3 \%$ of new cases with normal serum acid phosphatase levels at the time of the lymphogram have lymphographic evidence of lymph node spread. Higher incidences were seen in the late cases and many of these patients were thought clinically, radiologically, and biochemically to have disease limited to the local tumour site.

Criticism may be levelled at these results because of the lack of histological proof of the lymphatic metastases shown by the lymphogram. This information is, however, impossible to obtain unless a staging laporotomy is performed with radiographic control (Castellino et al. 1973), and in addition patients dying from advanced prostatic cancer do not in this country often come to necropsy. We feel that with regular follow-up radiographs, however, the difference between nodes affected by metastasis, reactive hyperplasia, infection, and fatty replacement soon becomes apparent. The importance of follow-up films cannot be overemphasized if a time-consuming technique is not to lose half its value. Six of our new cases (13.3\%) developed radiographically demonstrable lymphatic metastases between six and 15 months after the lymphogram without clinical or biochemical evidence of tumour spread.

\section{Conclusions}

If any radical treatment is proposed for carcinoma of the prostate it would seem desirable that a lymphogram should be performed as part of the initial series of investigations since if lymphatic involvement is shown treatment may have to be modified. Irradiation of the pelvis and prostate gland may well fail if paraaortic metastases $(24.4 \%$ of our new cases) are present and, similarly, radical prostatectomy is inadvisable without a negative lymphogram having been first obtained. In addition, the results of radiotherapy and chemotherapy in those patients with involved nodes may be simply followed up by repeat radiographs and treatment modified as necessary.

Lymphography also gives the clinician an added dimension in investigating early cases. Slightly less than $50 \%$ of new patients with normal acid phosphatase levels and no evidence of skeletal metastases have been shown to have lymphographic evidence of lymph node deposits. Lymphography seems to give an earlier and more accurate indication of extraprostatic spread than measurement of the acid phosphatase level.

\section{References}

Arduino, L. J., and Glucksman, M. A. (1962). fournal of Urology, 88, 91. Bloom, H. J. G., and Hendry, W. F. (1973). In Modern Trends in Oncology 1 Part 2, ed. R. W. Raven, p. 143. London, Butterworths

Castellino, R. A., et ai. (1973). Fournal of the American Medical Association, 223, 877 .

Castellino, R. A. (1974). Personal communication.

Fischer, H. W. (1969). In Lymphography in Cancer. ed. W. A. Fuchs, J. W. Davidson, and H. W. Fischer, p. 28. London, Heinemann.

Flocks, R. H., Culp, D., and Porto, R. (1959). Fournal of Urology, 81, 194.

Grossman, I., et al. (1974). American fournal of Roentgenology, Radium Therapy and Nuclear Medicine, 120, 673.

Macdonald, J. S. (1973). British fournal of Hospital Medicine, 9, 437.

Macdonald, J. S. (1974). In Complications in Diagnostic Radiology, ed. G. Ansell. Oxford, Blackwell. In press.

McCullough, D. L., Prout, G. R., and Daly, J. J. (1974). Fournal of Urology, 111,65 .

Ray, G. R., Cassady, J. R., and Bagshaw, M. A. (1973). Radiology, 106, 407. Whitmore, W. F., and Mackenzie, A. R. (1959). Cancer, 12, 396. 